Nepal Journal of Multidisciplinary Research (NJMR)

Vol. 4, No. 4, December 2021. Pages: 1-22

ISSN: 2645-8470 (Print), ISSN: 2705-4691 (Online)

DOI: https://doi.org/10.3126/njmr.v4i4.43023

\title{
Information Technology Outsourcing in Nepal: Strengths, Challenges, and Priorities
}

\author{
Sushil Paudel \\ PhD Scholar, Mewar University, Rajasthan, India \\ Dr. SN Agal \\ Mewar University, Rajasthan, India \\ Dr. Vinish Kumar \\ Sanskar College of Engineering and Technology, Gaziabad, India
}

\section{Corresponding Author}

Sushil Paudel

Email: sushilpaudel@gmail.com

Received: September 09, 2021; Revised \& Accepted: December 28, 2021

(C) Copyright: Paudel (2021).

\section{(c) (1) (9)}

This work is licensed under a Creative Commons Attribution-Non Commercial 4.0 International

License.

\begin{abstract}
Nepal has been unable to capitalize on its growth potential in information technology outsourcing, despite being located on the borders of two of the world's largest outsourcing providers - India and China. The IT outsourcing industry plays a major role in driving socioeconomic growth. IT outsourcing success is largely determined by the vendor's internal strength, industry-specific environmental factors, and country-specific policies. This research is focused on outsourcing strategies on vendor's perspective, as many emerging markets including Nepal continue to struggle to establish a foothold in the international market. The respondents included outsourcing companies, freelancers, consultants, and policymakers, and the quantitative data was collected using a snowball sampling method inside the Kathmandu valley. The variables were drawn based on the expert's advice and a review of the literature. Cronbach's Alpha was used to test data for reliability, and results were validated using convergent and discriminant validity. The analysis included descriptive
\end{abstract}




\section{Nepal Journal of Multidisciplinary Research (NJMR) \\ Vol. 4, No. 4, December 2021. Pages: 1-22 \\ ISSN: 2645-8470 (Print), ISSN: 2705-4691 (Online) \\ DOI: https://doi.org/10.3126/njmr.v4i4.43023}

analysis followed by structural equation modelling. The study identified six key strategic factors for emerging market: banking priority to IT outsourcing industry, growth capacity of the service provider, intellectual property, country specific specialization, foreign direct investment, and the HR structure of the vendor. It is suggested that policymakers of emerging nations incorporate IT outsourcing in their economic strategy and develop a baseline framework that includes these success factors.

Index Terms - Confirmatory Factor Analysis, Business Process Outsourcing, Emerging Market, Exploratory Factor Analysis, Outsourcing Strategy, Structural Equation Modelling

\section{Introduction}

Outsourcing has arisen as one of the areas of investigation for a multitude of sectors in the ever-changing global economy (Asli et al., 2014). Information technology outsourcing is an unavoidable part of today's enterprises (Bapna et al., 2010) and growing in average of $4.4 \%$ each year since 2010 (Gartner, 2020). Outsourcing allows businesses to focus on their core competencies while delegating non-critical functions to external entities with proven expertise. Information Technology Outsourcing (ITO) boosts both the receivers' and providers' economies by assisting industrial activities and modernization.

ICT is one of the fastest growing sectors in Nepal, including the internet, telephone, mobile, ITeS and business process outsourcing. In general, IT developer costs in Nepal are lower than in other countries in South Asia. Nepal has been able to reach the world market to become an alternative offshore outsourcing venue for India, Pakistan and other Asian countries. The Nepalese time zone is ideal for companies seeking outsourcing from Europe and America. Many companies have consolidated their business in Nepal and have built an international niche market for their products (FNCCI, 2020). Around 5,500 Nepalese graduates join the IT sector every year. Moreover, the ongoing development in telecommunications and internet technology is a driver for the industry.

Nepal exported services amounting to 287 million (Trading Economics BoP, 2020) while the export of ICT services from India amounted to 78.5 billion US dollars and China to 25 billion US dollars (excluding manufacturing) in 2017, with a significant contribution to their GDP. A.T. Kearney, Inc (2017) showed that India is the most preferred location for outsourcing 


\section{Nepal Journal of Multidisciplinary Research (NJMR) \\ Vol. 4, No. 4, December 2021. Pages: 1-22 \\ ISSN: 2645-8470 (Print), ISSN: 2705-4691 (Online) \\ DOI: https://doi.org/10.3126/njmr.v4i4.43023}

services, followed by China, Malaysia, Indonesia, Brazil, Vietnam, Philippines, Thailand, Chile, and Colombia. Similarly, Sri Lanka, Poland, Mexico, Egypt, Bulgaria, Czech Republic, Germany, Romania, and UK are some of the other successful countries.

Nepal is still on an emerging stage and struggling to make their presence felt on the international market, though, Nepal provides distinct benefits as a destination for BPOs (MOCIT, 2019). The objective of the research is to identify the business success factors of information technology outsourcing in Nepal, being Nepal as a vendor to the global community.

\section{Literature Review}

In 1971, the first computers appeared in Nepal to carry out the census. In 1975, the National Computer Center was founded as an Electronic Data Processing Center. However, personal computers emerged on the market only after 1985. They were soon followed by private training and programming institutes that served the computer-related needs of private companies (Investment Board Nepal, 2017). In 2000, the government's IT strategy promised that Nepal will be on the world IT map for the next five years. As part of Nepal Trade Integration Strategy, the Government has listed IT and business process outsourcing as a priority of 5 potential export services sectors. The ITES-BPO sector has three types of companies: (i) local solutions providers (off shoring centers) comprised of domestic oriented companies, (ii) export-oriented companies, and (iii) hybrids. International markets are the focus of export-oriented enterprises; the hybrid providers focus on both domestic and international markets. In 2000, The Computer Association of Nepal (CAN), an umbrella organization of the IT Industry, announced a target of 5 billion rupees in five years for export revenues from software industry (Upadhaya, 2006), however, even after 20 years, country is still more behind the goal, while the CAN figure should have crossed.

In Nepal, ICT-related services are open to foreign direct investment. Up to $80 \%$ stakes in telecommunications-related enterprises are permitted, whereas for IT and IT-enabled services, 100\% FDI is allowed. Call centers, medical transcription services, geographical 


\section{Nepal Journal of Multidisciplinary Research (NJMR) \\ Vol. 4, No. 4, December 2021. Pages: 1-22 \\ ISSN: 2645-8470 (Print), ISSN: 2705-4691 (Online) \\ DOI: https://doi.org/10.3126/njmr.v4i4.43023}

information systems, data mining services, animation services and back-office data processing firms compose companies working in this sector (Investment Board Nepal, 2017).

As per Ministry of Communication and Information Technology of Nepal, The IT outsourcing industry plays a major role in driving socio-economic growth, as it is important for all industries and generates a large number of jobs. In contrast to other Southeast Asian BPO companies in India, China and the Philippines, Nepali outsourcing companies provide services for fair rates. Nepal offers distinct benefits as a BPO destination, due to lower wages/costs and lower employee turnover. The IT outsourcing sector also has enormous potential for continuing development in the near future because of its huge young, skilled and low-wage English-speaking workforce. Around 5,500 Nepalese graduates join the IT sector each year. The Government of Nepal established a Master Plan for ICT in Education (201317) to help digitize the country's education system, making ICT-enabled education services a particularly attractive investment route.

\subsection{Strength}

In Nepal, the IT services sector is nascent but increasing. The sector can be divided into three areas: (a) application services (e.g. app development, consulting and integration of systems); (b) IT-enabled services and business process outsourcing; and (c) products (for example, ecommerce, internet service providers, online payments, and mobile wallets). Companies are more export-oriented in the first two segments, offering services to international markets, such as call centers, medical transcripts, back offices, claims processing and the production of digital materials. In due course, IT services could contribute to Nepal's growth strategy by developing know-how in niche sectors that complement key sectors like tourism and agriculture. Increased production and product diversification of main export-oriented sectors like tourism could be supported in ICT goods and services. This may include real-time booking tools, property management systems, mobile services and flight integration, geolocation, and wearable mountain hiking technology applications. Other possible niche areas include other sectors' value chain operations that involve a high degree of local awareness and understanding (language, geography, culture, networks) to operate well. Potential examples include delivering online education services in remote Nepalese areas (unlike only education software), as well as transport and service productivity tools. 


\section{Nepal Journal of Multidisciplinary Research (NJMR) \\ Vol. 4, No. 4, December 2021. Pages: 1-22 \\ ISSN: 2645-8470 (Print), ISSN: 2705-4691 (Online) \\ DOI: https://doi.org/10.3126/njmr.v4i4.43023}

The industry is still small but rising quickly. Total revenue was projected to be $\$ 100-200$ million, \$50-\$100 million and \$50-\$100 million in FY 2016/17 respectively by the registered IT application services companies, ITeS-BPO service providers and e-commerce business. The Computer Association of Nepal says jobs in IT services are rising annually by between 15 and 20 percent. While systematic information on IT services companies is not available, anecdotal evidence is in general, that IT services companies in Nepal are small, some even not officially recorded. Most IT services firms hire only 5 to 20, and only about 10 businesses employ more than 100 staff. However, the industry has become a draw for entrepreneurial talent despite its modest scale. Mostly, innovative, and customized solutions for local problems are produced by Nepalese IT services firms which include accessible education, riding hailing and pharmaceuticals, hospitals, restaurants and hotel management systems. Many IT-enabled companies have been nurtured in recent years by an evolving ecosystem of digital entrepreneurship. Mentoring, access to networks and funding is provided by few local or foreign incubators and accelerators. Some accelerators help develop business models and expertise and provide co-working spaces. The low labor costs of young software developers have been a key factor in the growth of and rising exports of Nepal's software application market. Nepal has an hourly app development average of about $\$ 10-\$ 15.75$. This is lower than other significant Asian outsourcing nations, such as 50 dollars in China, 30 dollars in Vietnam, 20 dollars in the Philippines and 15 dollars in India. Nepal's low-wages cost about $\$ 220$ a month a junior software developer with less than 3 years' experience compared with an average of $\$ 500$ in other Asian countries (World Bank Group, 2018). IT services companies that take advantage of Nepal's salary advantage will continue to drive the sector in the short to medium term, although their salary advantages are likely to decrease over time. Nepal's IT companies operate primarily in segments in which entry barriers are minimal. Competition from other low-wage countries (and emerging technologies) is highly likely to increase over time. Indeed, the IT service sector in Nepal is not as big as the low-cost outsourcing industry in India; for example, only 7,500 students each year take courses in computer science/ICT in Nepal. Just 20 percent of these remain in Nepal. 2.6 million Indian

students by contrast graduated in 2016 from STEM courses. As such, Nepal will need to pursue a different growth strategy to India. 


\section{Nepal Journal of Multidisciplinary Research (NJMR) \\ Vol. 4, No. 4, December 2021. Pages: 1-22 \\ ISSN: 2645-8470 (Print), ISSN: 2705-4691 (Online) \\ DOI: https://doi.org/10.3126/njmr.v4i4.43023}

The IT services sector could also boost governance efficiency and accountability, thereby contributing to easing a significant cross-cutting constraint on the private sector. The government has for example, announced plans for e-governance, intelligent cities, and a national framework to boost domestic demand for IT application services. Although international standards remain weak, the IT services sector will eventually account for a significant proportion of good employment, if the business environment improves. Facing limitations, Nepal has a high degree of start-up dynamism. For several years, some IT services companies have managed to remain competitive on export markets. The IT services industry may also enjoy greater proximity to Indian countries: companies have benefited from India's experience, but also seem to have lost talent to India. Taping into India's diaspora and attracting Indian FDI could allow Nepal to enjoy its proximity to India.

One of the studies conducted by Dixit \& Lohani, 2017 shows Around 13\% of firms exported embedded software to foreign countries. Among them about $23 \%$ exported embedded software to the USA, $13 \%$ to the UK, $10 \%$ to Canada, India and Australia each, $7 \%$ to Netherlands, Thailand and Russia each and about $13 \%$ to other countries. About $32 \%$ firms exported business application software. Among them about $27 \%$ firms exported the software to the USA, $16 \%$ to the UK, $11 \%$ to Australia and $18 \%$ to European countries like Germany, France, and Netherlands. The other $28 \%$ exported to countries like China, India, Japan, Myanmar, New Zealand, Bhutan, Bangladesh and Africa. About 30\% firms exported web advertisement software to foreign countries: $22 \%$ to the USA, $20 \%$ to Australia, $15 \%$ to the

UK, 20\% to other European countries like Belgium, Germany, Switzerland, Poland, and Sweden, and $19 \%$ to India, Philippines, Russia, Japan, Hong Kong and Bangladesh and 4\% to Canada. About 24\% firms exported mobile application software to foreign countries: $30 \%$ firms exported to the USA, $15 \%$ to Australia, $11 \%$ to the UK, $9 \%$ to Canada , $14 \%$ to other European countries like Germany, Switzerland, Netherlands, and Sweden and $21 \%$ to Asian countries like India, China, Hong Kong, Singapore, South Korea, and Japan (Dixit \& Lohani, 2017).

\subsection{Issues}

Because of the lack of higher-level skills and management experience, businesses are limited from growing or increasing their quality level. In deep dives interviews in a study conducted 


\section{Nepal Journal of Multidisciplinary Research (NJMR) \\ Vol. 4, No. 4, December 2021. Pages: 1-22 \\ ISSN: 2645-8470 (Print), ISSN: 2705-4691 (Online) \\ DOI: https://doi.org/10.3126/njmr.v4i4.43023}

by IFC in 2018, companies found out that the lack of skilled technical and mid-level managers rendered expanding. Interviewees also noticed that many of them have to invest in six to eight months of on-the-job training due to the poor standard of professional training. The quality-adjusted costs of skilled labor are also high. The high rate of migration of skilled employees increases the supply of skilled technicians and managers. For example, emigration in the ICT sector leads to a high decline in employees and a shortage of the best IT graduates. Companies must actively invest in attracting and skilling graduates, with few remaining long enough to become middle managers.

As part of institution arrangement, Ministry of Information and Communication \& Ministry of Science, Technology and Environment work on policy level while Nepal Telecommunication Authority and Department of Information Technology are regulatory and implementation bodies. Ineffective legislation and unsupportive policy make business challenging. Overlapping and ambiguous mandates have impeded policy alignment through main ministries: The Ministry of Information and Communication and the Ministry of Education, Sciences and Technology. The IT industry has little interface with government, partly because it has traditionally focused on IT hardware and local trade by the single industry community - Computer Association of Nepal. Furthermore:

- There is no regulation for the IT industry in segments such as IT outsourcing and ecommerce.

- Immigration laws limit the provision of international qualified employees.

- Only businesses with more than 300 workers can assert a tax exemption for IT companies.

- Privacy and intellectual property rights continue to be essential to businesses and endusers.

- Apart from the International Investment and Technology Transfer Act of 1992, there is no clear legal structure dealing with IT transmission issues.

- The IT policy of 2015, which aims to help the industry by improving infrastructure, digitizing public services, and supporting many IT sub-sectors, is still in draft form and is subject to public scrutiny.

- The lack of funding for early-stage financing and company incubation limits start-ups. A lack of funding for SMEs represents a cross-cutting constraint which presents IT 


\section{Nepal Journal of Multidisciplinary Research (NJMR) \\ Vol. 4, No. 4, December 2021. Pages: 1-22 \\ ISSN: 2645-8470 (Print), ISSN: 2705-4691 (Online) \\ DOI: https://doi.org/10.3126/njmr.v4i4.43023}

startups with special challenges. Some startup IT-service companies need $\$ 500,000$ to $\$ 1$ million to scale up, as found in the study, but they find it difficult to access longterm bank loans or equity investments of this size.

The IT services sector has also been affected by Nepal's poor IT infrastructure and lack of quality IT parks. First, IT companies are limited to the Kathmandu city, the only area with sufficient infrastructure. Secondly, the extremely low rate of broadband penetration and the mediocre quality and cost of mobile internet restrict domestic IT services demand. Specialized technology parks may contribute to adequate technical and infrastructural capability in a restricted area. But the only government-run IT Park in Nepal has struggled to attract companies, mainly because of weak infrastructure. Other infrastructural problems include high and fixed logistics infrastructure costs (relative to the size of the market in Nepal) and absence of a standardized postal address system. Cash remains the preferred payment choice among online shoppers in Nepal. The online transaction cost of the purchase or leasing of point of service terminals and the high transaction fees (between 1.75 percent and 3 percent) is higher. The transaction costs are also longer than in other countries in Nepal (around 45 days). Various studies show that the key constraints of the IT Outsourcing sector in Nepal are:

a. Limited technological and management knowledge and experience followed by low quality technical education and high turnover of talent

b. Regulatory issues like framework for e-commerce and outsourcing missing, visa difficulties for skilled foreigners, weak IP enforcement capacity

c. Access to finance like missing market between seed funding and mature stage capital and Challenging FDI regulations

d. Digital infrastructure issues such as ICT infrastructure is costly, low quality and concentrated in the Kathmandu Valley, E-payment infrastructure is nascent and dysfunctional IT Park.

Local businesses have many problems with the management of workers, cultural problems, the readiness of networks, internet stagnation and so on. It should be appreciated that businesses, who have survived and are growing amid high insurance costs, a negative investment rating on global markets and average infrastructure (Upadhaya, 2006). Nepal 


\section{Nepal Journal of Multidisciplinary Research (NJMR) \\ Vol. 4, No. 4, December 2021. Pages: 1-22 \\ ISSN: 2645-8470 (Print), ISSN: 2705-4691 (Online) \\ DOI: https://doi.org/10.3126/njmr.v4i4.43023}

lacked major IT outsourcing or BPO company that thrives on ICT infrastructure and local talent. The robust IT infrastructure and civic facilities as an electrical supply have been a crucial prerequisite for large IT companies to flourish (MOCIT, 2019).

Import and export of IT software and services are troublesome. Around $20 \%$ of respondents were unhappy with government import policy in a survey conducted by Dixit and Lohani. During transactions across borders, they faced difficulties, especially with customary procedures and when paying for added value tax (VAT). The lack of sufficient online banking, foreign currency purchases, and the lack of credit card systems were problems that $13 \%$ of respondents found. Around $20 \%$ had problems with payment transfers (Dixit \& Lohani, 2017).

\subsection{Opportunities}

The computer market in Nepal is rising rapidly and can provide more Nepalese people with jobs and income if properly created. The 2010 IT policy of the government could act as a tool for the growth of this sector, but it is still to be enforced. Nepal has a ready supply of young people who want to know about the growth of software and could enable companies to expand in the next generation and beyond. Challenges such as increased cost of production and lack of information about project management must however be addressed if investors still worried about investment in Nepal are to be attracted. Nepal cannot compete with other computer hardware manufacturing countries, but in the contrary, software can be produced. Capacity growth on technological aspects and project management is important for young professionals to achieve this objective. At the same time, foreign exposure of small entrepreneurs should be provided to build their capacity and reinvest in the software industry. Recently, women's participation in the IT sector has increased. New opportunities for women must be developed. This will include identifying policy gaps and creating a framework to develop gender equity effectively in the sector. Similarly, daily computer market surveillance will help improve the sector to become a source of the country's foreign exchange profits. Educational investments will build skills and capacity to deliver goods that meet international standards. Finally, the emphasis should move from supply side to control to make the sector a sustainable source of income for IT agencies in the country (Dixit \& Lohani, 2017). 


\section{Nepal Journal of Multidisciplinary Research (NJMR) \\ Vol. 4, No. 4, December 2021. Pages: 1-22 \\ ISSN: 2645-8470 (Print), ISSN: 2705-4691 (Online) \\ DOI: https://doi.org/10.3126/njmr.v4i4.43023}

Relatively unrestrained by Nepal's poor physical infrastructure, logistics, high land prices and a limited domestic market, the IT services sector will broaden good job opportunities for skilled youth, increase competitiveness in other sectors and promote good governance (World Bank Group, 2018). Few of the Opportunities are a. In general, IT developer costs are lower in Nepal than in other countries in South Asia. b. Nepal was able to reach the foreign market to become an alternative offshore outsourcing venue for India, Pakistan and other countries in Asia. c. For companies seeking outsource from America and Europe, the Nepali time zone is advantageous (FNCCI, 2020). The opportunities can be classified as short-run, low to midrange and medium to long term. Short run opportunities can be achieved from export-oriented IT services firms leveraging low-wage advantage. Low to mid-range opportunities can be leveraged from BPO and data analytics. E-commerce for domestic market shall be medium to long term opportunity and including niche products, digitization, value chain activities like remote education services, potentially exportable innovative products; clean energy software, mountain hiking and tourism apps, geolocation and meteorology apps leveraging home market advantage.

\subsection{Foreign Direct Investment}

The new Foreign Investment and Technology Transfer Act 2019 is expected to provide the impetus to Nepal's quest to attract more foreign investment into the country through streamlined and simplified procedures and clarity of law. The maximum limit for foreign investment in Nepal has not been prescribed in the law, However The current minimum investment threshold for a foreign investor is NPR 50 million (approximately USD 450,000). After obtaining the approval of the Securities Board of Nepal by setting up a venture capital fund, a foreign investor may also invest in the shares of a business in Nepal. Department of Industries (DOI) approves for investments up to NPR 6 billion (up to USD 50Million) whereas investors should contact Investment Board of Nepal for investments above NPR 6 billion ((> USD 50Million). As specified in Industrial Enterprises Act 2016, the Ministry of Industry, Commerce \& Supplies has established a Single Point Service Center. All services required by an industry including concessions, facilities and incentives shall be provided through this Centre in an easy and spontaneous manner. Foreigners and companies can open and operate bank accounts in any commercial bank in Nepal and transact in the Nepalese 


\section{Nepal Journal of Multidisciplinary Research (NJMR) \\ Vol. 4, No. 4, December 2021. Pages: 1-22 \\ ISSN: 2645-8470 (Print), ISSN: 2705-4691 (Online) \\ DOI: https://doi.org/10.3126/njmr.v4i4.43023}

currency, foreign currency or both (with prior approval of NRB). Foreign investors can utilize a range of foreign exchange facilities in the open market for payment to experts, highly skilled technicians, managerial level employees; payment of the principal or interest of bond or debenture and Repatriation of income invested and earned by an entity.

Hiring of expatriates as management experts, technical experts, managerial, and technical staff can be undertaken by entities only when qualified Nepali nationals are not available for such positions. The companies must provide the Nepalese workers with training and development to replace these expatriates. Furthermore, the Labour law has restricted the number of expatriates that can be hired by an entity to a maximum of $5 \%$ of the total workforce. An entity with approved foreign investment can acquire land for setting up an industry, or alternatively lease land for this purpose. Where land cannot be identified by the investor, or where the land required is in excess of the prescribed ceiling, the approving authority shall provide necessary arrangement, approval and facilitation to identify the required land.

To attract foreign investment in Information Technology and special industries, government has given concessions in annual/net revenue up to 30 percentage if the employment is generated more than 1000 and additional 10\% if the employment is 33\% inclusive of women, oppressed or handicapped person. Up to $80 \%$ stakes in telecommunications-related enterprises are permitted, whereas for IT and IT-enabled services, $100 \%$ FDI is allowed (Investment Board Nepal, 2017). These attractions have mild to nil effects to foreign investors in comparing to neighboring and other south east Asian countries who offer tax exemption to staff and company for multiple years, eases visa and travel facilities, easy crosscountry transactions, allocate required infrastructure with priority and offers gesture to investors

\subsection{Priority Interventions}

IFC has suggested following immediate intervention in November 2018:

- Improve access to skills through a collaboration between Ministries of Education, IT and Industry to revise graduate courses and introduce IT internship program. 


\section{Nepal Journal of Multidisciplinary Research (NJMR) \\ Vol. 4, No. 4, December 2021. Pages: 1-22 \\ ISSN: 2645-8470 (Print), ISSN: 2705-4691 (Online) \\ DOI: https://doi.org/10.3126/njmr.v4i4.43023}

- Improve firm capabilities by supporting the development of more business incubators and introducing subsidized management extension programs for IT firms.

- Improve access to serviced land and infrastructure by upgrading the existing IT Park with greater private sector involvement, and by developing a reform plan for ICT infrastructure sector.

In recent years, IT industry has expanded rapidly, partly due to Nepal's low wages, but all retained the absence of higher IT and managerial capacity in the workforce, regulatory hurdles, poor digital infrastructure, and access to finances (World Bank Group, 2018). Further, IT Outsourcing sector immediately needs priority interventions on the following segment:

1. Framework for e-commerce and outsourcing.

2. Easy visa allocation to skilled foreigners

3. Encourage IP and improve Intellectual Property enforcement capacity

4. Access to finance like missing market between seed funding and mature stage capital

5. Regulations to attract more Foreign Direct Investment

e. Good quality digital resources such as the internet at lower prices

f. International Payment infrastructure

g. Operate IT Park in full function with improved facilities and broader vision.

h. Cultivate country specific products.

\section{Research Methodology}

This is an exploratory study based on quantitative data. The study was carried out in 3 districts of Kathmandu valley viz., Kathmandu, Lalitpur and Bhaktapur, the capital city of Nepal. Sample size was 385 and the respondents were IT outsourcing companies, government employees, freelancers, and outsourcing experts. Structured questionnaire was used as an instrument designed in 5-point Likert scale starting from 5 (Strongly Agree), 4 (Agree), 3 (Neutral), 2 (Disagree), and 1 (Strongly Disagree). The questionnaire was distributed to 10 subject experts for content validity. All observed and unobserved variables were selected from the literature review, and, from the input of industry experts. About 10\% questionnaire was tested for reliability using Cronbach's Alpha. It was validated with face and content validity. Questionnaire was designed both on English and Local Nepali language. 


\section{Nepal Journal of Multidisciplinary Research (NJMR) \\ Vol. 4, No. 4, December 2021. Pages: 1-22 \\ ISSN: 2645-8470 (Print), ISSN: 2705-4691 (Online) \\ DOI: $\underline{\text { https://doi.org/10.3126/njmr.v4i4.43023 }}$}

\subsection{Data Collection}

Office of the Company Registrar in Nepal registers the IT companies and indexes as per the international industrial code. Though there are industrial codes for various software development and hardware companies, no such code is assigned for IT outsourcing companies, and hence, this makes is difficultly to identifying the actual population. As per Investment Board Nepal (2017), there are 256 companies legally registered in Nepal out of 6,000 BPO businesses. The snowball sampling technique was used to reach new respondents based on a previous recommendation. Respondents were also identified using personal contacts and search engines. Prior approval or consent was obtained, and the information of the respondent was kept confidential on ethical grounds.

The questionnaire was distributed personally, by email and by using an enumerator. 403 responses were collected out of 590 and 385 respondents were selected after removing missing and unusual records. The number satisfies the sample size for unknown population using the formula $\left.\mathrm{n}=\left(\mathrm{z}^{2} * \mathrm{p} * \mathrm{q}\right) / \mathrm{e}^{2}\right)$ where $\mathrm{z}=1.96$ at $95 \%$ confidence level, $\mathrm{p}=$ standard deviation $=0.5$ (maximum variability of the population at $50 \%), q=1-\mathrm{p}, \mathrm{e}=$ margin of error $(0.05)$.

\subsection{Data Validation}

Reliability coefficient Cronbach's $\alpha$ was used to check the reliability of the collected data. Cumulative Cronbach $\alpha$ was found to be 0.901 , and the value suggests that the instrument is reliable. A reliability test of individual factors was also conducted, Alpha value based on covariance ranged from 0.688 to 0.894 and the same based on correlation ranged from 0.715 to 0.896 (Table 1) and hence considered reliable for further analysis.

Table 1: Test of Reliability, Adequacy and Sphericity

\begin{tabular}{|c|c|c|c|c|c|c|c|}
\hline \multirow[t]{2}{*}{ Latent Variable } & \multicolumn{3}{|c|}{ Reliability Statistics } & \multirow{2}{*}{$\begin{array}{l}\text { KMO } \\
\text { Measure } \\
\text { of } \\
\text { Sampling } \\
\text { Adequacy }\end{array}$} & \multicolumn{2}{|c|}{$\begin{array}{l}\text { Bartlett's Test of } \\
\text { Sphericity }\end{array}$} & \multirow[b]{2}{*}{ Sig } \\
\hline & $\begin{array}{l}\text { Cronbach's } \\
\text { Alpha }\end{array}$ & $\begin{array}{l}\text { Alpha Based } \\
\text { on } \\
\text { Standardized } \\
\text { Items }\end{array}$ & $\mathrm{N}$ & & $\begin{array}{l}\text { Approx. } \\
\text { Chi- } \\
\text { Square }\end{array}$ & df & \\
\hline $\begin{array}{l}\text { Strategic Success } \\
\text { Factors }\end{array}$ & & & & & & & \\
\hline Internal Factor & .688 & .715 & 9 & .678 & 786.109 & 36 & .000 \\
\hline External Factors & .832 & .836 & 7 & .804 & 1041.989 & 21 & .000 \\
\hline Policy Factors & .894 & .896 & 15 & .784 & 3104.846 & 105 & .000 \\
\hline
\end{tabular}




\section{Nepal Journal of Multidisciplinary Research (NJMR) \\ Vol. 4, No. 4, December 2021. Pages: 1-22 \\ ISSN: 2645-8470 (Print), ISSN: 2705-4691 (Online) \\ DOI: https://doi.org/10.3126/njmr.v4i4.43023}

The Kaiser-Meyer-Olkin measure of sampling adequacy was tested for each latent variable and the values were observed between 0.67 and 0.80. Similarly, Bartlett's test of sphericity was highly significant $(\mathrm{p}=000)$ for all variables. Result of these tests justifies that the data is suitable for factor analysis.

\section{Analysis}

Data was analyzed in two stages: descriptive and factor analysis. The questionnaire consisted of 31 observed variables distributed to three latent variables: internal strategic factor (9), external environmental factor (7), and policy factors (15). Internal factors are related to organizational strength, external factors to environment factors like business competition and policy factors to laws and policies in place. The objective of the statistical analysis is to identify most important success factors that can utilized as a baseline framework for the growth of information technology outsourcing in Nepal.

\subsection{Descriptive Analysis}

There were three types of respondents - top-level management, managers, and officers. Top level management includes CEO, Managing Director, Founder and Co-Founder. Manager level includes CIO, IT Manager, IT Head, Deputy Manager, Sr. IT Officer. Similarly, officer level includes IT Officer, System Administrator, Database Expert, Network Administrator, Information Security Officer, HR Officer, Procurement and Finance Officer. Individual experts are present and previous consultants to IT outsourcing companies or the individuals who provide freelance services using freelance marketplace like freelancer, Upwork, fiverr, Toptal, Dribble, StartUpers, Gister, Folyo, Clarity, Behance etc. Managers participating were $46.2 \%$ (178) followed by officers with $36.1 \%$ (139) and top-level management $17.7 \%$ (68). Among the respondents from IT Outsourcing Company employees, 38.4\% (78) respondents are managers, $34.0 \%$ (69) respondents are officers and $27.6 \%$ (56) are top level management. Similarly, among the respondents from public organization, 59.6\% (34) respondents are officers with highest rank, 36.8\% (21) respondents are managers and 3.5\% (2) are top level management. There is no specific position in relation to individuals. Among the respondents, $61.3 \%$ (236) had master's degree education and rest had bachelor's degree with $38.75 \%$ (149). The respondents have experience range of 6-10 years with highest rank followed by 


\section{Nepal Journal of Multidisciplinary Research (NJMR)}

Vol. 4, No. 4, December 2021. Pages: 1-22

ISSN: 2645-8470 (Print), ISSN: 2705-4691 (Online)

DOI: https://doi.org/10.3126/njmr.v4i4.43023

$22.3 \%(86)$ with $11-15$ years of experience, $22.1 \%$ (85) with less than 5 years' experience, $17.7 \%$ (68) with 16-20 years of experience and 6.5\% (25) respondents with greater than 21 years of experience in the IT outsourcing sector. Out of 385 valid respondents, there were respondents ranging from 1 year to 39 years of experience and the mean value is 11.68 years and standard deviation of 5.953. Highest number were from Kathmandu with $71.9 \%$ (277) and lowest from Bhaktapur 4.2\% (16). Respondents from Lalitpur are 23.9\% (92).

The mean value of Own Intellectual Property (4.65) and Product Expertise (4.65) are equal followed by Meet the Compliance (4.52), Capacity to Grow (4.51), Global Image of the Country (4.49), Competitive Market Place (4.42) and IT Infrastructure (4.41) while Demographic Information and Trends (3.87) has the lowest (table 2).

Table 2: Mean and Standard Deviation of observed variables

\begin{tabular}{|c|c|c|}
\hline Variable & Mean & $\begin{array}{l}\text { Std. } \\
\text { Deviation }\end{array}$ \\
\hline Own Intellectual Property & 4.65 & .476 \\
\hline Product Expertise & 4.65 & .645 \\
\hline Meet the Compliance & 4.52 & .681 \\
\hline Capacity to Grow & 4.51 & .662 \\
\hline $\begin{array}{l}\text { Global Image of the } \\
\text { Country }\end{array}$ & 4.49 & .761 \\
\hline Competitive marketplace & 4.42 & .724 \\
\hline IT Infrastructure & 4.41 & .643 \\
\hline $\begin{array}{l}\text { Interaction } \\
\text { between IT } \\
\text { companies }\end{array}$ & 4.40 & .743 \\
\hline \begin{tabular}{ll} 
Formulate & \multicolumn{2}{c}{ Government } \\
Agency to Promote IT \\
Outsourcing
\end{tabular} & 4.35 & .842 \\
\hline $\begin{array}{ll}\text { Country } & \text { Specific } \\
\text { Specialization } & \end{array}$ & 4.33 & .811 \\
\hline Strong Sales Team & 4.31 & .833 \\
\hline $\begin{array}{l}\text { Government Policies and } \\
\text { Preferences }\end{array}$ & 4.30 & .869 \\
\hline More IT Colleges & 4.29 & .790 \\
\hline Minimize production costs & 4.29 & .652 \\
\hline FDI on IT Outsourcing & 4.27 & .869 \\
\hline HR Structure & 4.23 & .727 \\
\hline $\begin{array}{l}\text { Knowledge sharing } \\
\text { activities between the }\end{array}$ & 4.18 & .752 \\
\hline
\end{tabular}

\begin{tabular}{|c|c|c|}
\hline countries & & \\
\hline $\begin{array}{l}\text { Cooperation and } \\
\text { Collaboration with foreign } \\
\text { companies }\end{array}$ & 4.16 & .730 \\
\hline Market Demand & 4.16 & .833 \\
\hline $\begin{array}{l}\text { Possibility of market } \\
\text { penetration }\end{array}$ & 4.15 & .849 \\
\hline $\begin{array}{l}\text { Adjustment of Taxes and } \\
\text { Tariffs }\end{array}$ & 4.15 & .916 \\
\hline $\begin{array}{ll}\text { Banking Priority to } \\
\text { Outsourcing Sector }\end{array}$ & 4.06 & .778 \\
\hline $\begin{array}{l}\text { Training Centers as per } \\
\text { Global Demand }\end{array}$ & 4.05 & .816 \\
\hline Minimize Brain Drain & 4.05 & 1.027 \\
\hline Price sensitivity & 4.05 & .709 \\
\hline Increase Efficiency & 4.00 & .942 \\
\hline $\begin{array}{l}\text { Develop an Outsourcing } \\
\text { Zone }\end{array}$ & 4.00 & .835 \\
\hline $\begin{array}{l}\text { Recognition of } \\
\text { Outsourcing Companies }\end{array}$ & 3.96 & .770 \\
\hline Pool of IT Experts & 3.92 & .732 \\
\hline $\begin{array}{l}\text { Competition's } \quad \text { Staying } \\
\text { Power }\end{array}$ & 3.89 & 1.057 \\
\hline $\begin{array}{l}\text { Demographic Information } \\
\text { and Trends }\end{array}$ & 3.87 & .823 \\
\hline Valid N (listwise) & 385 & \\
\hline
\end{tabular}

Out of 385, $252(65.5 \%)$ respondents strongly agree and $133(34.5 \%)$ agree on the requirement of own intellectual property of the service provider for the smooth growth of outsourcing business. None of the respondents stayed neutral or disagreed on this point. 285 


\section{Nepal Journal of Multidisciplinary Research (NJMR) \\ Vol. 4, No. 4, December 2021. Pages: 1-22 \\ ISSN: 2645-8470 (Print), ISSN: 2705-4691 (Online) \\ DOI: https://doi.org/10.3126/njmr.v4i4.43023}

(74\%) of respondents strongly agreed and $64(16.6 \%)$ agreed on the requirement of product expertise on the vendor while $36(9.4 \%)$ were neutral. 360 (93.5\%) emphasized on the regulatory compliance for the growth of a company while $17(4.4 \%)$ were neutral and 8 (2.1\%) disagreed. The vendors capability to grow is another factor agreed by $349(90.6 \%)$ respondents while $36(9.4 \%)$ were neutral. 227 (59\%) of the respondents strongly agreed on the effect of global image of country on promoting outsourcing business which is also agreed by $137(35.6 \%)$ respondents while 9 (2.3\%) did not disagree on it. Details of the major observed variables with their scale is listed in the table 3 .

Table 3: Frequency table of variables with higher mean value

\begin{tabular}{|c|c|c|c|c|c|c|c|c|c|c|}
\hline \multirow[t]{2}{*}{ Variable } & \multicolumn{2}{|c|}{ Strongly Agree } & \multicolumn{2}{|c|}{ Agree } & \multicolumn{2}{|c|}{ Neutral } & \multicolumn{2}{|c|}{ Disagree } & \multicolumn{2}{|c|}{$\begin{array}{l}\text { Strongly } \\
\text { Disagree }\end{array}$} \\
\hline & Frequency & Percent & $\mathbf{F}$ & $\mathbf{P}$ & $\mathbf{F}$ & $\mathbf{P}$ & $\mathbf{F}$ & $\mathbf{P}$ & $\mathbf{F}$ & $\mathbf{P}$ \\
\hline Own Intellectual Property & 252 & 65.5 & 133 & 34.5 & & & & & & \\
\hline Product Expertise & 285 & 74.0 & 64 & 16.6 & 36 & 9.4 & & & & \\
\hline Meet the Compliance & 232 & 60.3 & 128 & 33.2 & 17 & 4.4 & 8 & 2.1 & & \\
\hline Capacity to Grow & 231 & 60.0 & 118 & 30.6 & 36 & 9.4 & & & & \\
\hline Global Image of Country & 227 & 59.0 & 137 & 35.6 & 12 & 3.1 & 1 & .3 & 8 & 2.1 \\
\hline Competitive marketplace & 190 & 49.4 & 181 & 47.0 & 6 & 1.6 & & & 8 & 2.1 \\
\hline IT Infrastructure & 189 & 49.1 & 163 & 42.3 & 33 & 8.6 & & & & \\
\hline Country Specific Specialization & 194 & 50.4 & 139 & 36.1 & 36 & 9.4 & 16 & 4.2 & & \\
\hline Foreign Direct Investment on IT & 187 & 48.6 & 131 & 34.0 & 59 & 15.3 & & & 8 & 2.1 \\
\hline Outsourcing & & & & & & & & & & \\
\hline HR Structure & 157 & 40.8 & 161 & 41.8 & 67 & 17.4 & & & & \\
\hline $\begin{array}{l}\text { Banking Priority to Outsourcing } \\
\text { Sector }\end{array}$ & 99 & 25.7 & 233 & 60.5 & 39 & 10.1 & 6 & 1.6 & 8 & 2.1 \\
\hline
\end{tabular}

\subsection{Factor Analysis}

Factor analysis is a technique commonly used for data reduction and summary. It reduces highly correlated variables to a manageable level for interpretation when there are large number of variables. The study has utilized both exploratory and confirmatory factor analysis to identify, design and validate the structural model.

The data was initially analyzed using exploratory factor analysis which is a procedure generally used for data reduction and summarization. Principal Component Analysis initially extracted 29 Variables out of 31 in 9 groups using Varimax Rotation. Variables with less than 0.5 factor loading, negative factor loadings and cross loadings were removed. As CFA utilizes maximum likelihood to extract variables, final extraction was further refined using Maximum Likelihood and Varimax Rotation that decreased the groups into 2. Internal factors 


\section{Nepal Journal of Multidisciplinary Research (NJMR)}

Vol. 4, No. 4, December 2021. Pages: 1-22

ISSN: 2645-8470 (Print), ISSN: 2705-4691 (Online)

DOI: $\underline{\text { https://doi.org/10.3126/njmr.v4i4.43023 }}$

had 5 observed variables while External and Policy Factors are merged in a single latent variable 'external factors' with 15 observed variables, as given in table 4.

Table 4: Rotated Factor Matrix reduced latent variables to two categories

\begin{tabular}{lll}
\hline Observed Variables & & Factor \\
& External Factors & Internal Factors \\
\hline \hline Own Intellectual Property & & .730 \\
HR Structure of the company & & .600 \\
Product Expertise & & .449 \\
Capacity to Grow & & .774 \\
Meet the Compliance & & .562 \\
Competitive marketplace & .639 & .460 \\
Possibility of market penetration & .691 & \\
Government Policies and Preferences & .604 & \\
Adjustment of Taxes and Tariffs & .617 & .745 \\
More IT Colleges & .622 & \\
FDI on IT Outsourcing & .725 & \\
Training Centers as per Global Demand & .636 & .394 \\
Formulate Government Agency to Promote IT Outsourcing & .575 \\
Interaction program between IT outsourcing companies & .815 \\
Knowledge sharing activities between the countries & .724 & \\
Cooperation and Collaboration with foreign companies & .441 & \\
Banking Priority to Outsourcing Sector & .487 & \\
Country Specific Specialization & & \\
Recognition of Outsourcing Companies & & \\
Pool of IT Experts & & \\
\hline
\end{tabular}

Extraction Method: Maximum Likelihood.

Rotation Method: Varimax with Kaiser Normalization.

a. Rotation converged in 3 iterations.

To further refine the factors, the variables collected from EFA were plotted in CFA using IBM SPSS AMOS 26. When the model was plotted and executed, there were 230 distinct sample moments, 61 parameters to be estimated and 169 Degrees of Freedom. Chi-square value was 2161.539 and Probability level of 0.000. Observed variables with lower factor loadings were removed until the model fit was achieved. Covariance analysis was based on maximum likelihood with unbiased covariances supplied as input. The output computed were standardized estimates, squared multiple correlations, sample moments, factor score weights, covariances and correlations. The resulting model has Chi-square value of 17.865, degrees of freedom 6 and probability level of 0.007 and this was achieved by using the modification indices. As shown in figure 1, error levels e12 and e16 are correlated and error levels e13 and e19 are correlated. Also, the variables HR Structure and FDI has factor coefficients less than 


\section{Nepal Journal of Multidisciplinary Research (NJMR) \\ Vol. 4, No. 4, December 2021. Pages: 1-22 \\ ISSN: 2645-8470 (Print), ISSN: 2705-4691 (Online) \\ DOI: https://doi.org/10.3126/njmr.v4i4.43023}

0.7 but these variables were selected due to their correlations with other observed variables for best model fit.

\section{Findings}

Total six variables were identified as strategic success factors with model fit, 1. Banking Priority to IT Outsourcing Industry 2. Country Specific Specialization 3. Foreign Direct Investment on Information Technology 4. Vendor's Capacity to Grow 5. Own Intellectual Property and 6. Vendor's HR structure. Figure 1 shows the model achieved using CFA. Though the mean value of few other factors were high, those variables were removed by factor analysis due to multi-collinearity and validity measures. Strategic success factors are synonymous to 'setup quality' as they emphasize on the basic readiness factors that every nation and service provider should consider enhancing the outsourcing business.

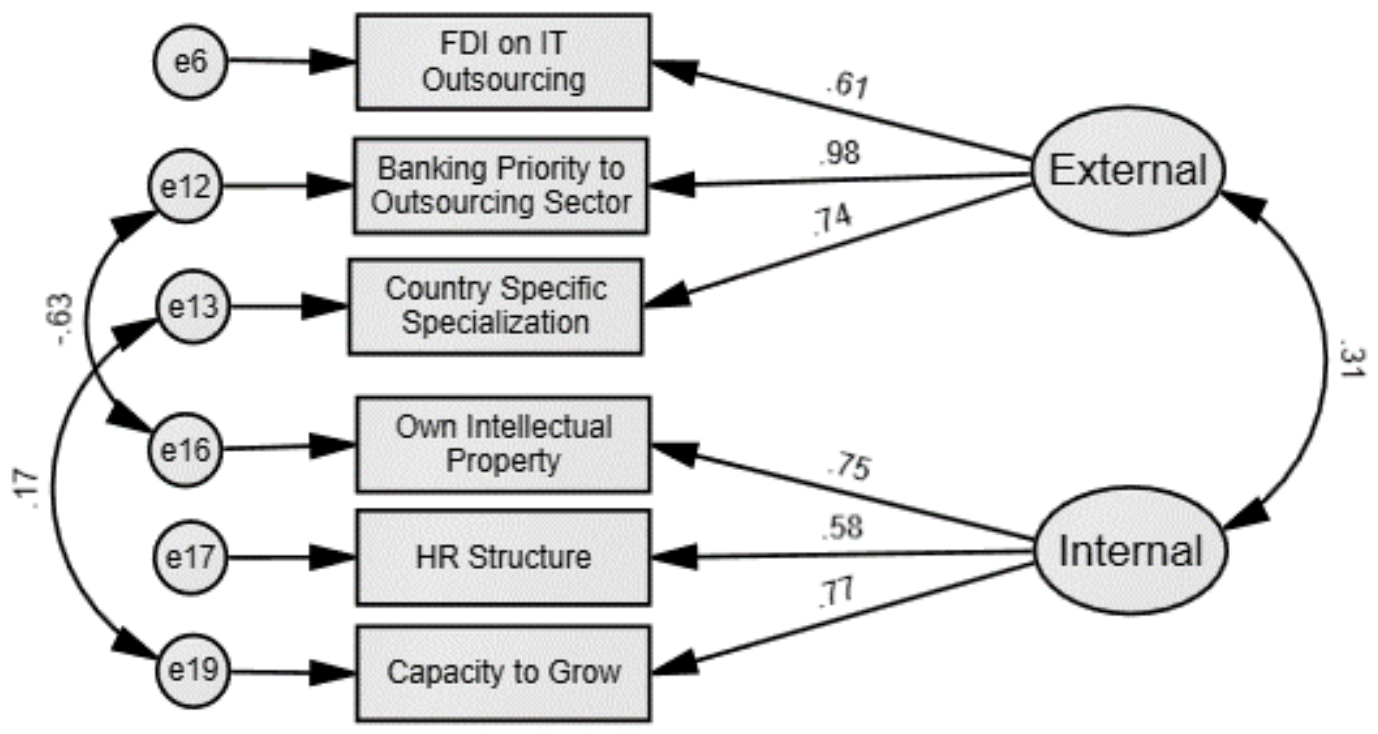

Figure 1: Structural Equation Modeling for Strategic Factors on Model Fit

\subsection{Model Fit Measures}

Model Fit measures were evaluated, and the result was found to be satisfactory. CMIN/DF has value of 2.978, CFI is 0.985, SRMR is 0.047, RMSEA is 0.072 and PClose 0.148 . Table 5 shows the interpretation of each measurement scales as described by Gaskin and Lim (2016). 


\section{Nepal Journal of Multidisciplinary Research (NJMR) \\ Vol. 4, No. 4, December 2021. Pages: 1-22 \\ ISSN: 2645-8470 (Print), ISSN: 2705-4691 (Online) \\ DOI: https://doi.org/10.3126/njmr.v4i4.43023}

Table 5: Model Fit Indices

\begin{tabular}{llll}
\hline Measure & Estimate & $\begin{array}{l}\text { Threshold (Gaskin \& } \\
\text { Lim, 2016) }\end{array}$ & $\begin{array}{l}\text { Interpretation } \\
\end{array}$ \\
\hline \hline CMIN (Chi-square statistics) & 17.865 & -- & -- \\
DF (Degrees of Freedom) & 6.000 & -- & -- \\
CMIN/DF & 2.978 & Between 1 and 3 & Excellent \\
CFI (Comparative Fit Index) & 0.985 & $>0.95$ & Excellent \\
SRMR (Standardized Root Mean Residual) & 0.047 & $<0.08$ & Excellent \\
RMSEA (Root Mean Square Error of & 0.072 & $<0.06$ & Acceptable \\
Approximation) & & & Excellent \\
PClose (p value when RMSEA is $>0)$ & 0.148 & $>0.05$ & \\
\hline
\end{tabular}

\subsection{Validity Test}

The values of $\mathrm{CR}, \mathrm{AVE}, \mathrm{MSV}$ and $\operatorname{MarR}(\mathrm{H})$ shows that the model is valid. AVE of the InternalFactors is 0.497 which is very near to the threshold of 0.5 ; value of CR, MSV and $\operatorname{MaxR}(\mathrm{H})$ are within the threshold and hence, the resulting model is valid (Table 6).

Table 6: Model Fit Measures

\begin{tabular}{lllllll}
\hline Latent Variables & $\begin{array}{l}\text { CR* } \\
(>0.7)\end{array}$ & $\begin{array}{l}\text { AVE* } \\
(>0.5>\end{array}$ & $\begin{array}{l}\text { MSV* } \\
(<\mathrm{AVE})\end{array}$ & $\begin{array}{l}\text { MaxR(H)* } \\
(>0.7)\end{array}$ & $\begin{array}{l}\text { External } \\
\text { Factors }\end{array}$ & Internal Factors \\
\hline \hline External Factors & 0.829 & 0.627 & 0.097 & 0.962 & 0.792 & \\
Internal Factors & 0.745 & 0.497 & 0.097 & 0.765 & $0.312^{* * *}$ & 0.705 \\
\hline
\end{tabular}

$* * * \mathrm{p}<0.001$

*CR (Composite Reliability), AVE (Average Variance Extracted is used to test Convergent Validity), MSV (Maximum Shared Variance is used to test Discriminant Validity), MaxR(H): Maximal Reliability

\section{Discussion and Conclusion}

The following table represents the pictorial format of the findings. Stakeholders and service providers shall prioritize the implementation of these factors for rapid changes in the industry. Not only Nepal, but the following factors are equally importance to other emerging countries who are struggling to mark their footprint in the outsourcing market.

\section{Internal Strategic Factor}

External Strategic Factor

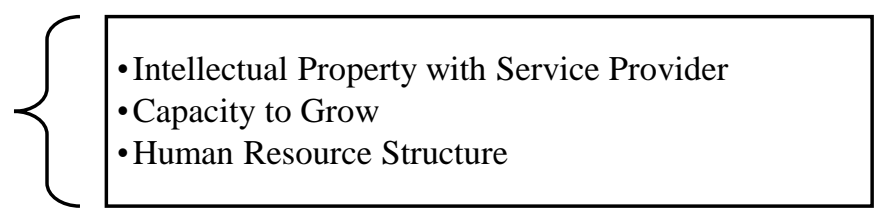

- Human Resource Structure

- Foreign Direct Investment in Information

Technology Outsourcing

- Banking Priority to IT Outsourcing Sector

- Country Specific Specializatoin 


\section{Nepal Journal of Multidisciplinary Research (NJMR) \\ Vol. 4, No. 4, December 2021. Pages: 1-22 \\ ISSN: 2645-8470 (Print), ISSN: 2705-4691 (Online) \\ DOI: $\underline{\text { https://doi.org/10.3126/njmr.v4i4.43023 }}$}

\section{Figure 2: Tabular representation of Strategic Success Factors}

Intellectual Property with Service Provider: In the IT industry, owning propriety software or solutions, referred to as Intellectual Property, is critical to successful entrepreneurship. The more Intellectual Property it owns, the faster a corporation grows.

Capacity to Grow: An IT outsourcing company should be able to scale up in response to demand. Financial capacity, production capacity, distribution capacity, and human resource capacity are few examples of growth capacity.

Human Resource Structure: The highly qualified human resource is at the heart of the IT industry. Maintaining a strong relationship with customers requires a qualified and efficient workforce. Furthermore, employer employee relationships play an important role in the success of the outsourcing project. Therefore, human capital including their structure should be prioritized.

Foreign Direct Investment on Information Technology: According to UNCTAD, FDI inflows into Asia increased by $\$ 474$ billion in 2019 , despite the fact that the area remained a key FDI destination, accounting for more than $30 \%$ of worldwide FDI flows. Inflows to China increased slightly to a new record of $\$ 141$ billion. India's FDI has increased by $20 \%$ to $\$ 51$ billion, contributing to the country's rising FDI trend. Emerging countries have boosted FDI as well, but the amount is still small; for example, Nepal's FDI jumped from a three-year low of $\$ 67$ million in 2018 to $\$ 185$ million in 2019. However, in both China and India, the majority of investments have been made in the ICT sectors (UNCTAD, 2020). FDI facilitates the sharing of information, the transmission of cutting-edge technology, and the cultivation of innovative ideas, and should thus be viewed as a strategy for taking IT outsourcing to the next level.

Banking Priority to IT Outsourcing Sector: Finance is the catalyst that helps shape new businesses, allowing them to capitalize on opportunities to expand, create more jobs, and fund other businesses. The effective use of financial instruments such as loans and investments is critical to the success of the IT Outsourcing business. High interest rates, low 


\section{Nepal Journal of Multidisciplinary Research (NJMR) \\ Vol. 4, No. 4, December 2021. Pages: 1-22 \\ ISSN: 2645-8470 (Print), ISSN: 2705-4691 (Online) \\ DOI: https://doi.org/10.3126/njmr.v4i4.43023}

value, inefficient and depleted banking, and restrictive central bank policies are toxic in emerging economies, and IT outsourcing requires special banking attention.

Country Specific Specialization: The world looks to China for hardware and India for software development. Country-specific specialization enables developing countries to attract more customers.

This paper makes an important contribution to identifying the strategic success factors of IT outsourcing from the vendor's perspective. The paper provides insight to the policy makers and service providers to adopt new strategies to mark their footprint in the global outsourcing market. Similarly, this study will assist researchers in widening their knowledge and incorporating the variables into future studies.

\section{References}

1. Asli, A., Eric, S., \& Nursel, O. (2014). Dynamic Strategic Supplier Selection System with Fuzzy Logic. Social and Behavioral Sciences (2nd World Conference on Business, Economics and Management - WCBEM 2013), 1059-1063. https://doi.org/10.1016/j.sbspro.2013.12.588

2. Bapna, R., Barua, A., Mani, D., \& Mehra, A. (2010). Cooperation, Coordination and Governance in Multisourcing: An Agenda for Analytical and Empirical Research. Information Systems, 21(4), 785-795. https://doi.org/10.1287/isre.1100.0328

3. Dixit, K. M., \& Lohani, R. D. (2017). Computerization in Nepal: State of hardware and software business. Kathmandu, Nepal: Institute for Social and Environmental Transition (ISET)-Nepal.

4. FNCCI (2020). Information Technology/ICT. Retrieved from Federation of Nepalese Chambers of Commerce and Industry: https://www.fncci.org/information-technologyict-151.html

5. Gartner.

(2020).

Retrieved

from

http://www.gartner.com/DisplayDocument?id=1881228\&ref='g_fromdoc'

6. Gaskin, J., \& Lim, J. (2016). Model Fit Measures. AMOS Plugin. Retrieved from Gaskination's StatWiki. http://statwiki.gaskination.com/index.php?title=Plugins 


\section{Nepal Journal of Multidisciplinary Research (NJMR) \\ Vol. 4, No. 4, December 2021. Pages: 1-22 \\ ISSN: 2645-8470 (Print), ISSN: 2705-4691 (Online) \\ DOI: $\underline{\text { https://doi.org/10.3126/njmr.v4i4.43023 }}$}

7. Investment Board Nepal. (2017). ICT Sector Profile. Retrieved from https://ibn.gov.np/wpcontent/uploads/2020/04/ICT-Sector-Profile.pdf

8. Kearney, A. T. (2017). Global services location index. Accessed October 10, 2018. Ahmad Al-Jarrah et al. / Journal of Computer Science 2021, 17 (5): 459.469 DOI: 10.3844/jcssp.2021.459.469

9. MOCIT, G. (2019). 2019 Digital Nepal Framework: Unlocking Nepal's Growth Potential. Kathmandu: Frost and Sullivan.

10. Trading Economics BoP. (2020, Octoer 31). Nepal - ICT Service Exports (BoP, Current US\$). Retrieved from Trading Economics: https://tradingeconomics.com/nepal/ict-service-exports-bop-current-us\$-wb-data.html

11. Upadhaya, G. R. (2006, March). Not doing too badly in IT Outsourcing. Retrieved July 04, 2013, from Nepali Times: http://nepalitimes.com/news.php?id=11426

12. World Bank Group. (2018). Creating Markets in Nepal: Country Private Sector Diagnostic. Washington, D.C.: IFC. https://elibrary.worldbank.org/doi/abs/10.1596/31006 